\title{
Half-leaf width symmetric distribution reveals buffering strategy of Cunninghamia lanceolata
}

Xi Peng ${ }^{1,2,3}$, Meifang Zhao ${ }^{1,2,3^{*}}$, Shuguang Liu ${ }^{1,2,3^{*}}$ and Wende Yan ${ }^{1,2,3}$

\begin{abstract}
Background: Leaf length and width could be a functioning relationship naturally as plant designs. Single-vein leaves have the simplest symmetrical distribution and structural design, which means that fast-growing single-vein species could interpret the scheme more efficiently. The distribution of leaf length and width can be modulated for better adaptation, providing an informative perspective on the various operational strategies in an emergency, while this mechanism is less clear. Here we selected six age groups of Cunninghamia lanceolata pure forests, including saplings, juveniles, mature, and old-growth trees. We pioneered a tapering model to describe half-leaf symmetric distribution with mathematical approximation based on every measured leaf along developmental sequence, and evaluated the ratio of leaf basal part length to total length (called tipping leaf length ratio).

Results: The tipping leaf length ratio varied among different tree ages. That means the changes of tipping leaf length ratio and leaf shape are a significant but less-noticed reflection of trees tradeoff strategies at different growth stages. For instance, there exhibited relatively low ratio during sapling and juvenile, then increased with increasing age, showing the highest value in their maturity, and finally decreased on mature to old-growth transition. The tipping leaf length ratio serves as a cost-benefit ratio, thus the subtle changes in the leaf symmetrical distribution within individuals reveal buffering strategy, indicating the selection for efficient design of growth and hydraulic in their developmental sequences.

Conclusions: Our model provides a physical explanation of varied signatures for tree operations in hydraulic buffering through growth stages, and the buffering strategy revealed from leaf distribution morphologically provides evidence on the regulation mechanism of leaf biomechanics, hydraulics and physiologies. Our insight contributes greatly to plant trait modeling, policy and management, and will be of interest to some scientists and policy makers who are involved in climate change, ecology and environment protection, as well as forest ecology and management.
\end{abstract}

Keywords: Leaf buffering strategy, Leaf width, Leaf length, Taper model, Regulation mechanism, Leaf biomechanics, Leaf morphology, Conifer

\footnotetext{
*Correspondence: t20131447@csuft.edu.cn; shuguang.liu@yahoo.com

${ }^{1}$ College of Life Science and Technology, Central South University of Forestry and Technology, Changsha 410004, Hunan, China

Full list of author information is available at the end of the article
}

(c) The Author(s). 2021 Open Access This article is licensed under a Creative Commons Attribution 4.0 International License, which permits use, sharing, adaptation, distribution and reproduction in any medium or format, as long as you give appropriate credit to the original author(s) and the source, provide a link to the Creative Commons licence, and indicate if changes were made. The images or other third party material in this article are included in the article's Creative Commons licence, unless indicated otherwise in a credit line to the material. If material is not included in the article's Creative Commons licence and your intended use is not permitted by statutory regulation or exceeds the permitted use, you will need to obtain permission directly from the copyright holder. To view a copy of this licence, visit http://creativecommons.org/licenses/by/4.0/ The Creative Commons Public Domain Dedication waiver (http://creativecommons.org/publicdomain/zero/1.0/) applies to the data made available in this article, unless otherwise stated in a credit line to the data. 


\section{Background}

Plants constantly buffer biophysical stress, mechanical resistance, and other environmental impacts for better adaptation and evolution throughout life stages $[1,2]$. The vascular tapering patterns revealed the buffering strategy is helpful to understand the hydrodynamical, biomechanical and geometrical design of plants based on the application of resource distribution theory under global warming trends [3]. This is mostly confirmed in roots, trunks, and branches of broad-leaved species, such as bamboo [4-7]. However, leaves acting as a transfer with external water vapor exchange constitute a substantial (up to 60\%) part of the resistance to water flow through plants, and thus influence transpiration, photosynthesis, and productivity [8]. Thus, the leaves seem to be more relevant for a sophisticated and effective hydraulic buffering strategy, exactly as leaf shape is finely tuned to adapt photosynthetic efficiency and hydraulic architecture [9]. The exploration of this phenomenon should therefore enhance our understanding of leaf design, plant architecture, and the hydraulic system of a self-similar fractal response to future climate change [2, 10-13].

Plant vascular tapering is demonstrated as conduits narrow in diameter along branch or root segments, while, how leaf width varies in leaf length segments is less concerned. Most studies have focused on which leaf vein tapering (e.g., midrib or veinlet) allows to decrease the path resistance and increase hydraulic capacity relative to construction costs [14-16]. But the leaf width shows tremendous variation based on similar vein tapering mechanisms $[7,17,18]$. Significantly, leaf width contributes more constraints to hydraulic design, because the maximum mesophyll hydraulic pathway is determined by leaf width $[14,19]$. Thus, it is universally accepted that broadleaves hold more complicated transport network or higher vein density to meet the wider structural construction, experiencing substantial evolutionary advantages, while the needles are cylindrical and take only one vein [19-21]. For single-vein leaves, mechanical reinforcement and moderate physiological process are on the strength of no more than one porous transport pipe without 'plan B' as a consequence [22]. Nevertheless, higher costs in leaf width might incur higher costs in water-sourcing root biomass to supply the transpiration [23], either a direct reduction in net carbon gain and competitive growth, leading to a competitive disadvantage [24]. Like some needle species put in a pioneer and high productivity role than broadleaved species in the same climate regime [25], there should be a kind of leaf with only one vein to support moderate width, and further, still sustain high productivity. Additionally, traditional coarse data of simply leaf maximum or estimated mean width are not as accurate for predicting leaf hydraulic buffering, encouraging us to evaluate width along with length segments and simulate leaf distribution trajectory more precisely.

Taxonomists proposed that there was a simplest way to differentiate orbiculate leaf species, was to locate the axis or, in some cases, the zone of greatest leaf width that lay perpendicular to the axis of the greatest length (long axis) [26]. The leaf is divided into two parts (basal part and distal part) depending on the zone [27]. Such as the tipping leaf length ratio (the ratio of basal part length to greatest length) is $2 / 5$ in ovate leaves, and $1 / 3$ in oblong leaves theoretically [26]. Leaf broadens to contain more structural buildings with an expansion of leaf length, and meets one part to stop widening, with leaf margin converging therewith. The tipping leaf length ratio represents that leaf reaches to the highest axial transport capacity and radial resistance. For quick adaptation, each leaf inherits the basal part length ratio, and modifies it within a shoot or crown, resulting in intraspecific differences [28]. However, less concentration has been devoted to exploring the temporal and spatial variation of such ratio. Whatever broadleaves or narrower leaves, different tipping leaf length ratio of leaves might be contributed to different functions of biomechanics and bioengineering, serving as the signal of buffering strategy, indicating developmental plastically superiorities [29-33].

Early predictors were devoted to testing the appropriate functionality and optimal cutting age of high yield and rapid growth for the selection of commercial trees in a breeding program. Fast-growing trees tend to be associated with elevated transpiration rates and higher hydraulic efficiency [34], thus sensible hydrodynamic variation performances were easier discovered comparing to slowgrowing species. For instance, Cunninghamia lanceolata as a representative species, is the most prevalent and widely distributed commercial evergreen in China. It has a long history of cultivating species for fast-growing and high productivity $[35,36]$. Besides, many forest management experience can provide us with the differentiation of growth stages and growth states.

Distribution of orbiculate leaf length and width diversity could be quantified with relevant characters and mathematical approximations (Fig. 1). According to most leaf length and half-leaf width variations, they might be functional relationships naturally as plant designs. There is possible to be many parabolic curves differing in skewness and kurtosis. It is intermediate between broad leaves and needles with moderate leaf width, as well as the conclusion drawn from their simple symmetric distribution can be generalized and followed. The symmetric distribution demonstrates the tipping length ratio is the largest leaf length divided by horizontal distance where derivative of function is zero. Here, we propose that: (1) the tipping leaf length ratio might be delicately varied in leaves within species; and (2) 


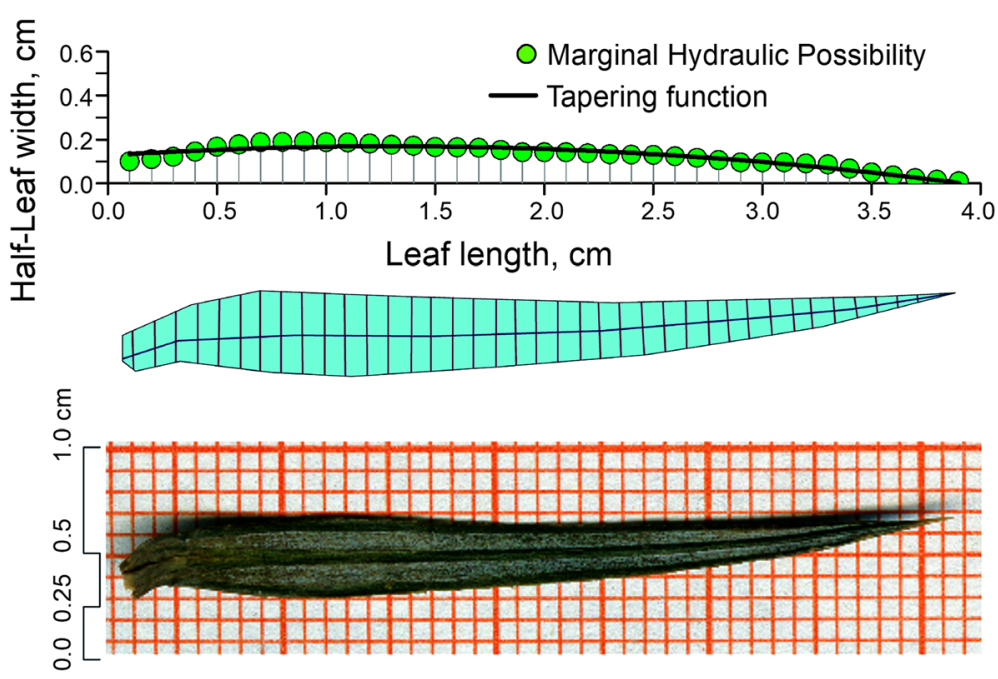

Fig. 1 A general model of leaf length and half-leaf width quadratic relationship, taken one C. lanceolata leaf as an example here (more details are shown in supporting information Fig. S1). The leaf width of needles universally ranges from 0.04 to $0.15 \mathrm{~cm}$, while broad leaves perform much wider (greater than $1 \mathrm{~cm}$ ) [37, 38]. Further, the modeled species C. lanceolata show somewhere in between. The images on the top, middle, below are the half-leaf width model, the contour extraction image and the original scanned image, separately. The data of the model come from the middle image, and blue line means leaf length between leaf petiole to tip along leaf midrib, red lines mean leaf widths at every $0.1 \mathrm{~cm}$ length segments. Green dots in the model represent half-leaf width marginal hydraulic possibility, and dark linear shows the leaf tapering function between half-leaf width $(Y)$ and leaf length $(X)$, which could be fitted as: $\boldsymbol{Y}=\boldsymbol{C}+\boldsymbol{B}_{1} \boldsymbol{X}+\boldsymbol{B}_{2} \boldsymbol{X}^{2}$. Diameters are shown in below image

buffering strategy would be caught in leaves according to the half-leaf distribution variation in different developmental stages. Our specific objectives are to: (1) construct a tapering model of leaf length and half-leaf width, predicting tipping leaf length ratio from leaf trajectory function, and take C. lanceolata as an example; (2) evaluate the models of half-leaf symmetric model in terms of its predictive power and applicability to unexplored leaf designations of buffering strategy and growing stages of development; and (3) discuss the possible constraints of leaf biomechanics and physiologies in hydraulic buffering.

\section{Results}

Means of leaf width varies from $0.222 \pm 0.08 \mathrm{~cm}$ for 23 yr-old, to $0.242 \pm 0.084 \mathrm{~cm}$ for 30 -yr-old among tree age gradients, and averages $0.234 \mathrm{~cm}$ in total (Fig. 2, Table 1). The 23-yr-old trees $(0.222 \pm 0.08 \mathrm{~cm})$ show significant lowest leaf width among the studied six age group trees while the 30 -yr-old $(0.242 \pm 0.084 \mathrm{~cm})$ shows significant highest value comparing to the rest five age groups $(p<$ $0.05)$. The trees in age from 2- to 13-yr-old show medium leaf width ranging from $0.252 \mathrm{~cm}$ to $0.247 \mathrm{~cm}$ (more details are shown in Table 1).

C.lanceolata half-leaf symmetric distributions show one widest part along leaf axis, and successfully demonstrate general quadratic growth functions (Fig. 2, Table S1). The variations of half-leaf tapering trajectories of C.lanceolata among different tree age groups are shown in Fig. 2. No logarithmic scale is used for better demonstrations of leaf length and half-leaf width trends. The leaves show a similar general pattern, with leaf length explaining 71.7 to $98.7 \%$ (averaged in $89.9 \%$ ) of the total half-leaf width variation. And the adjustment coefficient of determination (Adj. $\mathrm{R}^{2}$ ) of $58.3 \%$ of all models is above $90 \%$ (Table S1). Half-leaf width rises to the apex (the widest part of half-leaf width averages $0.165 \mathrm{~cm}$ ) then converges to maximum leaf length (averages $4.368 \mathrm{~cm}$ ) (More details are shown in Table 1). The final model of leaf length $(x)$ and half-leaf width $(Y)$ of each age group trees is as following:

2-yr-old tree: $Y=(0.142 \pm 0.005)+(0.005 \pm 0.004) x+$ $(-0.005 \pm 0.0008) x^{2}\left(\mathrm{R}^{2}=0.357, P<0.001\right)$

5-yr-old tree: $Y=(0.147 \pm 0.005)+(-0.008 \pm 0.005) x+$ $(-0.002 \pm 0.0009) x^{2}\left(R^{2}=0.275, P<0.001\right)$

10-yr-old tree: $Y=(0.142 \pm 0.003)+(-0.006 \pm 0.003) x+$ $(-0.005 \pm 0.0005) x^{2}\left(\mathrm{R}^{2}=0.498, P<0.001\right)$

13-yr-old tree: $Y=(0.138 \pm 0.004)+(-0.001 \pm 0.003) x+$ $(-0.002 \pm 0.0004) x^{2}\left(R^{2}=0.376, P<0.001\right)$

23-yr-old tree: $Y=(0.119 \pm 0.003)+(0.020 \pm 0.002) x+$ $(-0.007 \pm 0.0004) x^{2}\left(R^{2}=0.542, P<0.001\right)$

30-yr-old tree: $Y=(0.120 \pm 0.003)+(0.040 \pm 0.003) x+$ $(-0.014 \pm 0.0007) x^{2}\left(R^{2}=0.583, P<0.001\right)$

Leaf length shows a definite variation except in 30 -yrold groups (coefficient variations are $10.54 \%$, others range 20.05 to $24.88 \%$ ). There is no obvious tendency that leaf length increases or decreases with increasing tree age. Leaves in 30-yr-old are shorter than other age groups, especially significantly different from 13-yr-old tree age leaves $(4.024 \pm 0.424 \mathrm{~cm}$ and $4.887 \pm 1.169 \mathrm{~cm}$, 


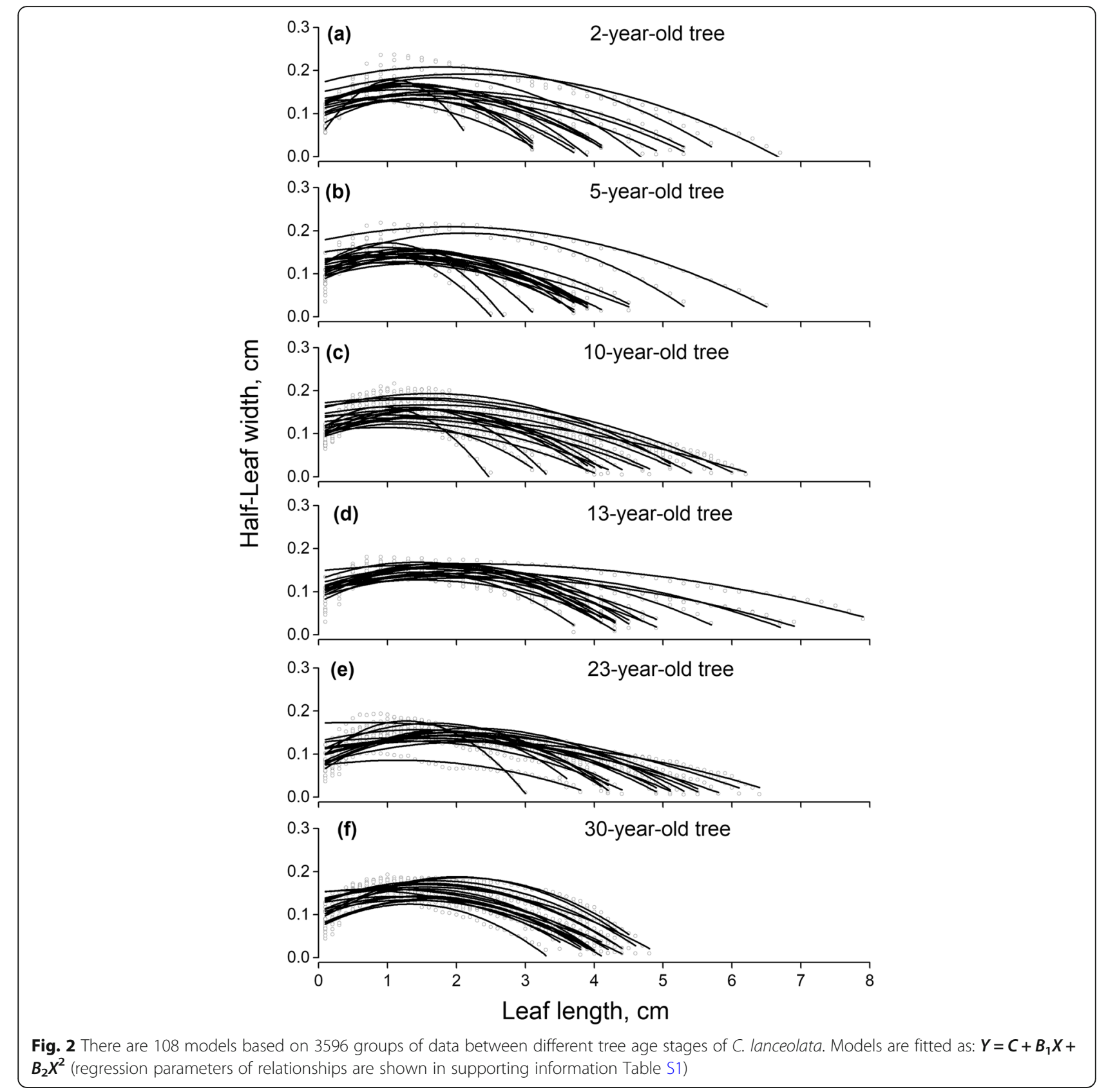

$p<0.05)$. Leaves in 5-yr-old trees also significantly shorter than 13 -yr-old trees $(3.977 \pm 0.904 \mathrm{~cm}, p<0.05$, more details are shown in Table 1).

Maximum leaf width averages in $0.329 \pm 0.043 \mathrm{~cm}$, and shows a decreasing trend with trees growth stages (from $0.346 \pm 0.055 \mathrm{~cm}$ in 2 -yr-old trees to $0.242 \pm 0.084 \mathrm{~cm}$ in 30 -yr-old trees, Fig. 3a, Table 1). Maximum leaf width in 2 -yr-old trees are significantly larger than in 30-yr-old trees, while there are no significant differences among 5-, 10-, 13- and 23-yr-old trees $(0.330 \pm 0.042 \mathrm{~cm}$, $0.331 \pm 0.048 \mathrm{~cm}, \quad 0.320 \pm 0.026 \mathrm{~cm}, \quad 0.334 \pm 0.034 \mathrm{~cm}$, respectively).
The measured data is fitted to determine the ratio between widest parts of leaf length from basal with total leaf length. The ratio floats in a certain range, varying from 0.303 for 10 -yr-old trees to 0.381 for 23 -yr-old trees, and averages 0.347 across tree age groups (Fig. 3b). The ratio decreases from 2-yr-old to 10-yr-old, then increases to 23yr-old, finally decreases after 23-yr-old as a whole. Moreover, 10-yr-old trees show significant lower ratios than 13 , 23 , and 30-yr-old trees $(0.365 \pm 0.05$ and $0.361 \pm 0.106$ for 13 and 30-yr-old trees length ratio, $p<0.05$ ), and 23 -yrold trees are significant higher than 5 -yr-old $(0.328 \pm 0.07)$ likewise (more details are shown in Table 1). 
Table 1 Statistical description of leaf width, maximum leaf width, leaf length and half-leaf tipping length ratio in tree age groups, using mean, standard deviation, standard error, 95\% confidential intervals (lower and upper value), median, minimum and maximum value

\begin{tabular}{|c|c|c|c|c|c|c|c|}
\hline Leaf parameter & $\begin{array}{l}\text { Tree } \\
\text { age } \\
\text { (year) }\end{array}$ & $\mathrm{N}^{*}$ & $\begin{array}{l}\text { Mean } \pm \\
\text { Standard } \\
\text { Deviation** }\end{array}$ & $\begin{array}{l}\text { Standard } \\
\text { Error }\end{array}$ & CV\%*** & $\begin{array}{l}\text { 95\% Confidence Interval } \\
\text { [Lower, Upper] }\end{array}$ & Median [Minimum, Maximum] \\
\hline \multirow[t]{7}{*}{ Width (cm) } & 2 & 386 & $0.241 \pm 0.098 \mathrm{ab}$ & 0.005 & 40.664 & {$[0.231,0.251]$} & $0.252[0.002,0.473]$ \\
\hline & 5 & 367 & $0.234 \pm 0.093 a b$ & 0.005 & 39.744 & {$[0.225,0.244]$} & $0.24[0.004,0.437]$ \\
\hline & 10 & 804 & $0.234 \pm 0.09 a$ & 0.003 & 38.462 & {$[0.228,0.24]$} & $0.246[0.01,0.434]$ \\
\hline & 13 & 452 & $0.23 \pm 0.081 \mathrm{ac}$ & 0.004 & 35.217 & {$[0.223,0.238]$} & $0.247[0.005,0.361]$ \\
\hline & 23 & 861 & $0.222 \pm 0.08 c$ & 0.003 & 36.036 & {$[0.217,0.228]$} & $0.236[0.012,0.388]$ \\
\hline & 30 & 740 & $0.242 \pm 0.084 b$ & 0.003 & 34.711 & {$[0.236,0.249]$} & $0.258[0.013,0.387]$ \\
\hline & Total & 3610 & $0.233 \pm 0.087$ & 0.001 & 37.339 & {$[0.23,0.236]$} & $0.246[0.002,0.473]$ \\
\hline \multirow[t]{7}{*}{ Maximum leaf width (cm) } & 2 & 18 & $0.346 \pm 0.055 a$ & 0.013 & 16.021 & {$[0.319,0.374]$} & $0.335[0.277,0.473]$ \\
\hline & 5 & 18 & $0.330 \pm 0.042 \mathrm{ab}$ & 0.010 & 12.699 & {$[0.310,0.351]$} & $0.326[0.277,0.437]$ \\
\hline & 10 & 18 & $0.331 \pm 0.048 \mathrm{ab}$ & 0.011 & 14.628 & {$[0.307,0.356]$} & $0.326[0.262,0.434]$ \\
\hline & 13 & 18 & $0.320 \pm 0.026 a b$ & 0.006 & 8.096 & {$[0.307,0.333]$} & $0.328[0.266,0.361]$ \\
\hline & 23 & 18 & $0.334 \pm 0.034 \mathrm{ab}$ & 0.008 & 10.176 & {$[0.317,0.351]$} & $0.334[0.278,0.387]$ \\
\hline & 30 & 18 & $0.310 \pm 0.040 \mathrm{~b}$ & 0.009 & 12.925 & {$[0.290,0.330]$} & $0.311[0.204,0.388]$ \\
\hline & Total & 108 & $0.329 \pm 0.043$ & 0.004 & 12.970 & {$[0.321,0.337]$} & $0.327[0.204,0.473]$ \\
\hline \multirow[t]{7}{*}{ Length (cm) } & 2 & 18 & $4.32 \pm 1.075 \mathrm{ab}$ & 0.253 & 24.884 & {$[3.785,4.854]$} & $4.240[2.881,6.823]$ \\
\hline & 5 & 18 & $3.977 \pm 0.904 \mathrm{a}$ & 0.213 & 22.731 & {$[3.527,4.426]$} & $3.95[2.433,6.421]$ \\
\hline & 10 & 18 & $4.518 \pm 0.99 \mathrm{ab}$ & 0.233 & 21.912 & {$[4.025,5.01]$} & $4.311[2.76,6.158]$ \\
\hline & 13 & 18 & $4.887 \pm 1.169 \mathrm{~b}$ & 0.276 & 23.921 & {$[4.306,5.469]$} & $4.430[3.702,7.826]$ \\
\hline & 23 & 18 & $4.484 \pm 0.899 a b$ & 0.212 & 20.049 & {$[4.036,4.931]$} & $4.690[2.879,6.092]$ \\
\hline & 30 & 18 & $4.024 \pm 0.424 \mathrm{a}$ & 0.100 & 10.537 & {$[3.814,4.235]$} & $4.110[3.225,4.887]$ \\
\hline & Total & 108 & $4.368 \pm 0.97$ & 0.093 & 22.207 & {$[4.183,4.553]$} & $4.243[2.433,7.826]$ \\
\hline \multirow[t]{7}{*}{ Half-leaf tipping length ratio } & 2 & 18 & $0.34 \pm 0.051 \mathrm{ab}$ & 0.012 & 15.000 & {$[0.315,0.366]$} & $0.348[0.191,0.425]$ \\
\hline & 5 & 18 & $0.328 \pm 0.075 \mathrm{ab}$ & 0.018 & 22.866 & {$[0.291,0.365]$} & $0.345[0.183,0.41]$ \\
\hline & 10 & 18 & $0.303 \pm 0.08 a$ & 0.019 & 26.403 & {$[0.264,0.343]$} & $0.319[0.123,0.409]$ \\
\hline & 13 & 18 & $0.365 \pm 0.051 b c$ & 0.012 & 13.973 & {$[0.34,0.391]$} & $0.362[0.272,0.441]$ \\
\hline & 23 & 18 & $0.381 \pm 0.104 c$ & 0.024 & 27.297 & {$[0.33,0.433]$} & $0.408[0.1,0.525]$ \\
\hline & 30 & 18 & $0.361 \pm 0.106 c$ & 0.025 & 29.363 & {$[0.308,0.414]$} & $0.358[0.155,0.593]$ \\
\hline & Total & 108 & $0.347 \pm 0.083$ & 0.008 & 23.919 & {$[0.331,0.362]$} & $0.352[0.1,0.593]$ \\
\hline
\end{tabular}

* $\mathrm{N}$ = sample size. ${ }^{* *}$ The differences of the means between tree age groups were tested using a One-Way ANOVA test (Fisher LSD test); different letters denote statistically significant $(p<0.05)$ differences between the means. ${ }^{* *} \mathrm{CV}=$ coefficient of variation

\section{Discussion}

\section{The relation of leaf length and width}

We pioneered a tapering model to intuitively describe the leaf length and width trajectory. Most studies were concentrated on measured leaf mean width and length, and their highly positive correlation $(r>0.5)$ [24]. Recently, many studies have proved that the relationship between leaf length and width is significant and implies evolutionary stability $[11,17]$. Taken $C$. lanceolata as an example, we evaluated the model among sapling, juvenile, mature, and old trees. Before maturity, the period of leaf expansion was longer in juvenile trees than in the younger trees. That is consistent with leaf expansion tendency in angiosperms (Euphorbiaceae), which holds that leaf support tissues are widespread in early allocation for establishing hydraulic and mechanical infrastructure and preparing for further photosynthesis [39, 40]. Moreover, we supplement the follow-up leaf elongation in mature and old trees, in which leaves become shorter and wider compared with saplings and juveniles, as reported for Douglas-fir, an evergreen needle trees with dramatically morphological differences in saplings and oldgrowth [41]. 

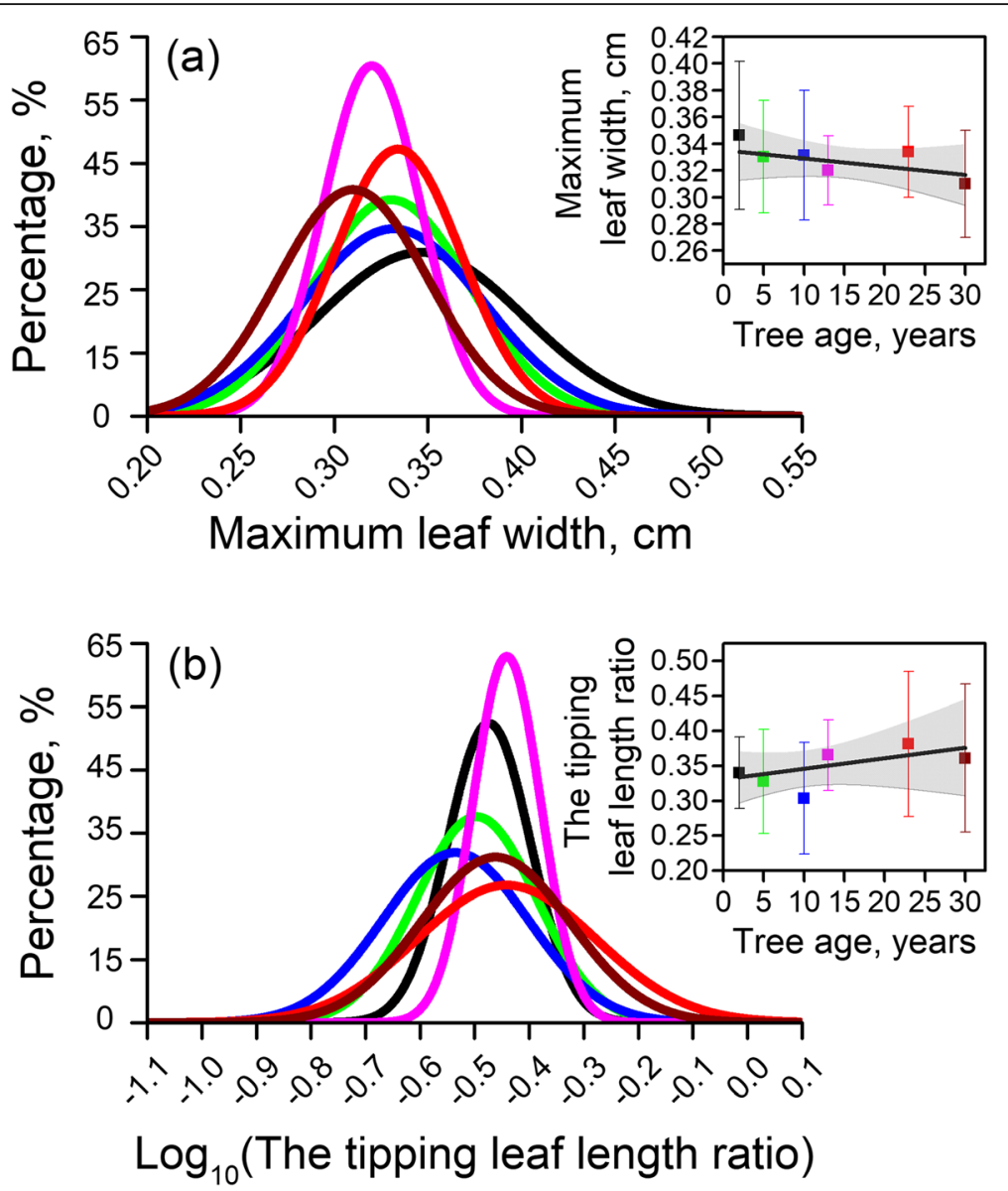

Fig. 3 Normal distribution curves of (a) maximum leaf width range and (b) tipping leaf length ratio among different tree age groups. Differences between leaf width and leaf length ratio in each leaf along tree age groups were tested using a One-Way ANOVA test (Fisher LSD test) of significance. The statistical frequency distributions of leaf width and tipping length ratio across tree age groups are presented in supporting information Fig. S2 and Fig. S3 separately

The specific parameters - leaf tipping length ratio Further, we use the leaf tipping length ratio to evaluate the predictive power and applicability of the model about buffering strategy in growing stages. Most studies preferred to link environmental gradients with leaf patterns such as leaf width or the ratio between leaf length and width [24, 42]. Such relationships are often much conflicting against in different areas and floras [42, 43]; additionally, the parameters are not very typical for leaf hydraulic buffering strategy in growing stages. Because trees vascular evolution by natural selection has acted to minimize hydrodynamic constraints, showing sufficiently or moderately tapering from base to tip length to buffer hydraulic resistance $[3,44,45]$. The tipping ratio on the basal part (the widest represents the highest radial resistance) length to maximum hydraulic possibility length is more representative to explore the buffering strategy in leaves. The estimated mean ratio (0.347) of C.lanceolata is close to the theoretical value of $2 / 5$ in ovate leaf, whose pattern is similar with elliptical in the basal part and parabolic in the distal part but much wider [26].

\section{The results of the parameter (leaf tipping length ratio) variations}

The leaf length tipping ratio of $C$. lanceolata floats in a certain range during their developmental sequences. The theoretical value of ideal leaf pattern in each case for particular species provides an example to describe and distinguish plant categories [26]. Yet, the certain range of ratio indicates leaf hydraulic buffering strategy to support the best possible adaptive modification of the preexisting hereditary type in different growth stages. For instance, our measured data and models generally state that leaves with decreasing tipping length ratio and increasing width tapering by trees maturing. When trees are mature (23-yr-old), they show a highest tipping length ratio (a larger basal part or a reduction of acuminate leaf tips), finally decline in old age. The results 
are similar to the former studies which reported from maize, tropical leaves, and conifers in Italy [9, 46-48]. The results also emerge as a signal that there possibly are functional constraints, biomechanical or physiological, operating in hydraulic buffering during growth process.

\section{The indication of the parameter variations -- biomechanics}

From the view of leaf biomechanics, wider leaves require a greater midrib component and its increase is consistently associated with divergence in leaf width [24]. Indeed, the leaf tapering operates as a cantilevered beam and, further, provides economical mechanical support, due to the load is on the most basal part $[15,49]$. The subtle fluctuation of the tipping length ratio proves that leaves can allow specialized biomechanical function to always ready to buffer different emergencies, such as wind, sun, and drought during their growth stages [5052]. For example, as C.lanceolata and other long grass leaves exhibit, shifting more biomass to the distal part allows leaves bending so that the center of the leaves is faced towards sunlight in the prime (10-yr-old), or more ratio to the basal part bears more environmental supports when plant toward ageing (23-yr-old) $[15,46]$. Besides, the ratio may increase with tree age or tree height, and the distal part is assumed to function as a way to quickly drain water from leaf surface and facilitate rapid drying [48]. Such function is reported as an adaptive strategy for tropical leaves [9].

\section{The indication of the parameter variations -- physiology}

The change of growth rate and physiological process may be another constraint in hydraulic buffering. Leaf growing in full sun and water is often limited by the ability of biophysical architecture to maintain sufficiently hydrated $[53,54]$. The tipping ratios are small in C.lanceolata saplings and juveniles, especially smallest in 10yr-old trees, then increase to 23-yr-old in largest, finally decline in old age. Such trends are similar to the anatomical studies that reported single-vein leaves vascular cylinders area variation for Douglas-fir [41]. C.lanceolata mostly lives under conditions of abundant light and water, while they develop shaded in the understory in early stages, herein, act as activism with much consideration on efficiency. As we find that sapling (younger than 10-year-olds) individuals show a relative low tipping ratio and wider leaves, existing a relative high value tapering. The smaller leaf tipping ratio is supposed to indicate the higher leaf hydraulic conductance. Because the lower tipping ratio shows the high values of leaf width and vein tapering, and the 'overtapering' conduit structures lead to the total hydraulic resistance being lower [44, 47]. Additionally, the lower tipping ratio of
C.lanceolata in elevated stages also entails higher gas exchange rate and higher relative growth rate for a given level of leaf carbon allocation $[8,15,55,56]$. In such case, a general trend of increased leaf size in plants suggests that they prefer economic benefits of larger leaf area to capture more light rather than biomass allocation [57-59], and offer their root and vascular system architecture for tree height and chest developments, reducing the proportion of leaf mechanical support [60, 61]. Single-vein leaves can increase in size only by increasing the distal part due to the hydraulic constraint on maximum width, and tapering improves hydraulic capacity relative to cost [30, 31, 50, 62]. WBE (West, Brown, Enquist) model holds that sufficient tapering in vascular system can offset path-length-reduced resistance in sapling samples [3], and further studies found hydraulic resistance was predicted to increase slightly with path length, inducing moderate tapering from saplings to adults $[44,63,64]$. Moreover, plant architecture and hydraulic system have existed as a self-similar fractal. We add to prove that leaves show the same tapering trend in samplings and juveniles. Moreover, according to the hydraulic vulnerability segmentation hypothesis, the larger distal parts of xylem pathway allow to buffer more basal part from hydraulic failure such as cavitation events, and therefore supply water is less expendable $[65,66]$. Therefore, for C.lanceolata, leaf hydraulic conductance may be high and rapid phases in the early, but slowdown growth in juveniles, and remain stable in established trees, moreover, an increase in old-growth. This can be proved from physiological studies, which believe plants greater access to water with deeper roots and attain powerful photosynthetic capacity with adequate photosynthetic area in the growing periods $[14,19]$, as well as it follows that plants have plenty of water supply to enable the stomata to remain open during the day $[67,68]$. More construction in wider vein with narrower leaf width favors mature individuals that do not wastefully allocate carbon or nitrogen [69-71], after their golden age, they transit to conservatism with a wider leaf and moderate cost-benefit ratio. Many reports have been managed to verify a transition of mature to old-growth plants on physiology [7274]. A relative long hydraulic pathway from vein through mesophyll tissue and moderate hydraulic efficient ratio render a relatively low hydraulic capacity, thereby limiting gas exchange to prevent the development of damaging water deficits [75].

\section{Conclusion}

Single-vein leaves have the simplest symmetric distribution and structural design, being regarded as an appropriate but less-focused sample to explore buffering strategy based on leaf morphology. We pioneered a tapering model to describe half-leaf symmetric 
distribution, which provided the trajectory of leaf length and width. The ratio of leaf basal part length to total length (called tipping leaf length ratio) were evaluated according to the model to investigate the tradeoff of leaves between highest axial transport capacity and radial resistance, and the changes of such tradeoff during tree growth stages, serving as the signal of buffering strategy, indicating developmental plastically superiorities. Our measured data and models generally state that leaves with decreasing tipping length ratio and increasing width tapering by trees maturing. When trees are mature (23-yr-old), they show the highest tipping length ratio (a larger basal part or a reduction of acuminate leaf tips), finally decline in old age. The results indicate that there possibly are functional constraints, biomechanical or physiological, operating in hydraulic buffering during growth process, besides, this could be manifested in leaf morphology. Using the leaf tapering model and tipping leaf length ratio, we can further extend the buffering strategy to other more complex leaf-shaped species, thoroughly investigating the tradeoff in leaf hydrodynamical, biomechanical and geometrical design during tree growth stages.

\section{Materials and methods}

\section{The model}

Previous have used many models to describe the leaf shape, for instance, the shape of bamboo leaves follows the simplified Gielis equation [18]. While for C. lanceolata, the model is aimed at simulating leaf length and width trajectory by single leaves, in terms of leaves geometric shapes which are ellipses and parabolas [26]. Parabolic model characterizes the half-leaf hydraulic possibility in terms of single leaf tapering shape (Fig. 1).

$$
Y=C+B_{1} X+B_{2} X^{2}
$$

(Y: Leaf half width, $\mathrm{X}$ : leaf length, $\mathrm{C}$ is constant representing intercept)

When $\frac{d Y}{d X}=0$, where $\mathrm{X}_{0}$ is the position of length, the maximum $Y$ is approached.

$$
\begin{aligned}
& B_{1}+2 B_{2} X_{0}=0 \\
& X_{0}=-\frac{B_{1}}{2 B_{2}}
\end{aligned}
$$

( $\mathrm{X}_{0}$ is the maximum width in the leaf length position)

$$
\text { Tipping leaf length ratio }=\frac{X_{0}}{X_{\max }}
$$

( $\mathrm{X}_{\max }$ is the leaf total length, while tipping leaf length ratio means the widest part of the leaf is on the axis in the basal ratio of the leaf)

\section{Leaf materials}

All plant materials were obtained from the wild with authorization and permission from one of national forest research station in China.

We choose Chinese fir (C. lanceolata) tree species as an example to test our modeling framework. The field studies did not involve endangered or protected species according to Chinese law and the Trade in Endangered Species of Wild Fauna and Flora (https://cites.org/). C. lanceolata is a coniferous tree species endemic to China, being one of the major fast-growing, high-yielding, and high-quality timber species in south China $[35,36]$.

The study area was Huitong National Forest Ecosystem Research Station located in Huitong, Hunan province, China $\left(25^{\circ} 50^{\prime} \mathrm{N}, 109^{\circ} 45^{\prime} \mathrm{E}\right)$. Experimental research on plants in long-term experimental stations and/or forest farms are encouraged according to policies and regulations of the state forestry administration in China and the outline of the national plan for medium- and longterm scientific and technological development. Organs of C. lanceolata were previously sampled and analyzed for several functional traits measured in young to mature-aged trees grown in wild at China forest station [36]. In the present study, we perform our investigation along tree growth development and across soil resource availability gradient. We obtained authorization and permission from the Huitong Forest Ecosystem Research Station to collect plant materials during the entire period of this study. Leave samplings and laboratory measurements were conducted in May 2018.

The site is dominated by a humid mid-subtropical monsoon climate, with warm and humid all year round. The annual mean temperature is $16.4{ }^{\circ} \mathrm{C}$, and mean annual precipitation is $1270-1650 \mathrm{~mm}$ occurring mostly between April and August (the data was provided by the China Meteorological Data Network (http://data.cma. gov.cn/site/index.html) and based on 1987-2015 normal). Average relative humidity exceeds $90 \%$ while average annual sunshine hours over $1350 \mathrm{~h}$ [29]. The soil is haplic alisols/haplic acrisols in World Taxonomy (clay loam red earth in Chinese Soil Taxonomy) developed from shale and slate parent rocks. The second generation of C.lanceolata forest was replanted in 1987, with an initial stand density of 3318 trees $\mathrm{hm}^{-2}$. The forest was nursed twice in spring and autumn in the first three years (1987-1990), and there was no tending and thinning management after 1990, which let the forest grow naturally [36]. The total forest density is about 2310 trees $\mathrm{hm}^{-2}$ at present. Six age groups of C.lanceolata trees existing within the research station were selected which are saplings $(2,5$, and 10-yr-old, occur naturally with no cultivation treatments), juveniles (13-yr-old), mature (23-yr-old), and old-growth individuals (30-yrold). Needles were selected 6-8 C.lanceolata trees which 
were well-growing and disease-free comprising different depths of canopy in each stands. Sampling leaves were placed in plastic bags with wet tissue inside and delivered to the laboratory. We selected leaves that apparently differed in size and shape, and collected 308 leaves per age group stands and 1848 leaves in total. All leaves were used immediately for the determination of further measurements.

\section{Leaf measurements}

All samples were scanned using an Epson Expression 11000XL Photo Scanner (Seiko Epson Inc., Tokyo, Japan), with the 600 dpi needed to clearly display leaf shape features was adopted (Fig. S1a). In order to acquire complete representations of leaf shape, sample images were with the help of a commercial graphic editor (AutoCAD, Autodesk Inc. San Rafael, CA, USA) to further clear backgrounds by smoothing and binary coding (Fig. S1b). A great effort was devoted to the image content digitization in this work. Data were obtained by applying a georeferencing framework with ARCGIS v9.3. (ESRI, Redlands, CA, USA) to the vector representation of leaf length and width based on artificial neural network (Fig. S1c) [69]. Leaf length was the distance between leaf base to blade tip along leaf midrib, and leaf length was divided into a number of sections per 0.1 or $0.2 \mathrm{~cm}$, while leaf widths were the distances perpendicular to midrib at every leaf length intervals (Fig. 1).

\section{Statistical analyses}

In order to simulate leaf length and half-leaf width distribution of C. lanceolata, we fitted leaf tapering function with parabolic models. The best 108 leaves were used to construct the leaf tapering models to calculate the average model in each age group trees and the remaining leaves were used to test the robust of the model and all leaves (308 leaves per age groups and 1848 leaves in total) are used in analysis. Means, standard deviation, 95\% confidential interval, median, minimum and maximum value were used to describe leaf width and tipping length ratio. We have checked normality of all data (Shapiro-Wilk normality test), and the tipping leaf length ratio was log10-transformed to test differences between each age groups. The differences between leaf width and tipping length ratio in each leaf among tree age groups were tested using a One-Way ANOVA test (Fisher LSD test) of significance. The model fitting, statistical description and ANOVA test were performed in software IBM SPSS Statistics v 21.0 (IBM Corp., Armonk, NY, USA). The charts were plotted in software OriginPro v 8.0 (OriginLab Co., Northampton, MA, USA) and R software version 3.6.1 (R Core Team 2019) [76].

\section{Supplementary Information}

The online version contains supplementary material available at https://doi. org/10.1186/s12870-021-03000-x.

Additional file 1: Figure S1. Data extraction processes of selected C. lanceolata leaves cross tree age stages ranging 2-yr-old to 30-yr-old, more details see Materials and Methods. (a) Original scanned image. (b) Smoothed and binary image. (c) Evaluation of leaf length and width by vectoring leaf margin using ArcGIS $\vee$ 9.3. The diameters are shown in images. Figure S2. Leaf width statistical frequency distribution across tree age gradients of $\mathbf{C}$. lanceolata. Figure $\mathbf{S 3}$. The tipping length ratio statistical frequency distribution across tree age groups of $C$. lanceolata. The plus and value showing in images represent mean value between groups.

Additional file 2: Table S1. Regression coefficients, $R^{2}$, horizontal and longitudinal distance of apex, and the ratio between the horizontal distances of apex with total length of main relationships used to estimate the length and half-leaf width trajectories in the selected leaves. The best fitting on leaf length $(X)$ and half-leaf width $(Y)$ is obtained by quadraticfunction models: $Y=C+B_{1} X+B_{2} X^{2}$, and all regressions have $p<0.0001$.

Additional file 3 .

\section{Acknowledgements}

This study could not have been completed without the cooperation and active assistance of many institutions and individuals. In particular, the authors would like to thank Jing Li, Weijia Li, and Zhiyuan Xiang, for their kind assistance with field investigation, leaf sampling and scanning. We are grateful to Wenhua Xiang, on behalf of Huitong National Forest Ecosystem Research Station, for his authorization and permission to collect plant materials during the entire period of this study (accessed May 2018). We are also deeply grateful for the friendliness and cooperation of the staff of the Huitong National Forest Ecosystem Research Station for helping us in gathering materials and for their kind assistance with the formal identification of the plant material used in our study. In addition, our special thanks go to our colleague Guangjun Wang for his constructive suggestions.

\section{Authors' contributions}

XP compiled data, MZ and SL performed analyses and developed theory. $M Z, X P$ and SL wrote the paper. WY involved in discussing the ideas and reviewing the manuscript. All the authors have read and approved the final manuscript.

\section{Funding}

This study was financially supported by the National Natural Science Foundation of China (Nos. 31600355 and 31971456), the Hunan Provincial Natural Science Foundation of China (Nos. 2020JJ4139 and 2019JJ40529), the Hunan Provincial Innovation Foundation For Postgraduate (CX20200703), and the Scientific Innovation Fund for Post-graduates of Central South University of Forestry and Technology (CX20201011).

Availability of data and materials

Data are made available as supplementary material.

\section{Declarations}

Ethics approval and consent to participate Not applicable.

\section{Consent for publication}

Not Applicable.

\section{Competing interests}

The authors declare that they have no competing interests.

\section{Author details}

${ }^{1}$ College of Life Science and Technology, Central South University of Forestry and Technology, Changsha 410004, Hunan, China. ${ }^{2}$ Huitong National Field Station for Scientific Observation and Research of Chinese Fir Plantation Ecosystem in Hunan Province, Huitong 410015, China. ${ }^{3}$ National Engineering 
Laboratory for Applied Forest Ecological Technology in Southern China Changsha 410004, China.

\section{Received: 24 February 2021 Accepted: 28 April 2021 Published online: 17 May 2021}

\section{References}

1. Pincebourde S, Woods HA. Climate uncertainty on leaf surfaces: the biophysics of leaf microclimates and their consequences for leaf-dwelling organisms. Funct Ecol. 2012;26(4):844-53. https://doi.org/10.1111/j.1365-243 5.2012.02013.x

2. Koch GW, Sillett SC, Jenning GM, Davis SD. The limits to tree height. Nature. 2004;428(6985):851-4. https://doi.org/10.1038/nature02417.

3. West GB, Brown JH, Enquist BJ. A general model for the structure, function, and allometry of plant vascular systems. Nature. 1999;400(6745):664-7. https://doi.org/10.1038/23251.

4. Savage VM, Bentley LP, Enquist BJ, Sperry JS, Smith D, Reich PB, et al. Hydraulic trade-offs and space filling enable better predictions of vascular structure and function in plants. Proc Natl Acad Sci U S A. 2010;107(52): 22722-7. https://doi.org/10.1073/pnas.1012194108.

5. McCulloh K, Sperry JS, Lachenbruch B, Meinzer FC, Reich PB, Voelker S. Moving water well: comparing hydraulic efficiency in twigs and trunks of coniferous, ring-porous, and diffuse-porous saplings from temperate and tropical forests. New Phytol. 2010;186(2):439-50. https://doi.org/10.1111/j.14 69-8137.2010.03181.x.

6. Lachenbruch B, McCulloh KA. Traits, properties, and performance: how woody plants combine hydraulic and mechanical functions in a cell, tissue, or whole plant. New Phytol. 2014;204(4):747-64. https://doi.org/10.1111/ nph.13035.

7. Huang W, Li Y, Niklas KJ, Gielis J, Ding Y, Cao L, et al. A superellipse with deformation and its application in describing the cross-sectional shapes of a square bamboo. Symmetry. 2020;12(12):2073. https://doi.org/10.3390/ sym 12122073

8. Sack L, Frole K. Leaf structural diversity is related to hydraulic capacity in tropical rain forest trees. Ecology. 2006;87(2):483-91. https://doi.org/10.1890/ 05-0710.

9. Cittadino E. Nature as the laboratory: Darwinian plant ecology in the German empire, 1880-1900: Cambridge University Press; 2002.

10. Choat B, Jansen S, Brodribb TJ, Cochard H, Delzon S, Bhaskar R, et al. Global convergence in the vulnerability of forests to drought. Nature. 2012; 491(7426):752-5. https://doi.org/10.1038/nature11688.

11. Shi P, Liu M, Ratkowsky DA, Gielis J, Su J, Yu X, et al. Leaf area-length allometry and its implications in leaf shape evolution. Trees. 2019;33(4): 1073-85. https://doi.org/10.1007/s00468-019-01843-4.

12. Shi P, Niinemets Ü, Hui C, Niklas KJ, Yu X, Hölscher D. Leaf bilateral symmetry and the scaling of the perimeter vs. the surface area in 15 vine species. Forests. 2020;11(2):246

13. Wang P, Ratkowsky DA, Xiao X, Yu X, Su J, Zhang L, et al. Taylor's power law for leaf bilateral symmetry. Forests. 2018;9(8):500. https://doi.org/10.3390/ f9080500.

14. Zwieniecki MA, Boyce CK, Holbrook NM. Functional design space of single-veined leaves: role of tissue hydraulic properties in constraining leaf size and shape. Ann Bot. 2004;94(4):507-13. https://doi.org/10.1 093/aob/mch173.

15. Sack $L$, Scoffoni C. Leaf venation: structure, function, development, evolution, ecology and applications in the past, present and future. New Phytol. 2013;198(4):983-1000. https://doi.org/10.1111/nph.12253.

16. Huang L, Niinemets Ü, Ma J, Schrader J, Wang R, Shi P. Plant age has a minor effect on non-destructive leaf area calculations in moso bamboo (Phyllostachys edulis). Symmetry. 2021;13(3):369. https://doi.org/10.3390/ sym13030369.

17. Shi P, Li Y, Niinemets Ü, Olson E, Schrader J. Influence of leaf shape on the scaling of leaf surface area and length in bamboo plants. Trees. 2020;35(2): 709-15

18. Shi P, Ratkowsky DA, Li Y, Zhang L, Lin S, Gielis J. A general leaf area geometric formula exists for plants-evidence from the simplified gielis equation. Forests. 2018;9(11):714. https://doi.org/10.3390/f9110714.

19. Brodribb TJ, Feild TS, Jordan GJ. Leaf maximum photosynthetic rate and venation are linked by hydraulics. Plant Physiol. 2007;144(4):1890-8. https:// doi.org/10.1104/pp.107.101352.
20. Boyce CK, Brodribb TJ, Feild TS, Zwieniecki MA. Angiosperm leaf vein evolution was physiologically and environmentally transformative. Proc $\mathrm{R}$ Soc B. 2009;276(1663):1771-6. https://doi.org/10.1098/rspb.2008.1919.

21. Ding J, Johnson EA, Martin YE. Optimization of leaf morphology in relation to leaf water status: a theory. Ecol Evol. 2020;10(3):1510-25. https://doi.org/1 0.1002 /ece 3.6004

22. Brodribb TJ, Feild TS. Evolutionary significance of a flat-leaved Pinus in Vietnamese rainforest. New Phytol. 2008;178(1):201-9. https://doi.org/1 0.1111/j.1469-8137.2007.02338.x.

23. Givnish TJ. Comparative studies of leaf form: assessing the relative roles of selective pressures and phylogenetic constraints. New Phytol. 1987; 106(s1):131-60

24. Tozer WC, Rice B, Westoby M. Evolutionary divergence of leaf width and its correlates. Am J Bot. 2015;102(3):367-78. https://doi.org/10.3 732/ajb.1400379.

25. Richardson DM. Ecology and biogeography of Pinus: Cambridge University Press; 2000.

26. Ellis B. Manual of leaf architecture: Published in association with the New York Botanical Garden; 2009

27. Verwijst T, Wen DZ. Leaf allometry of Salix viminalis during the first growing season. Tree Physiol. 1996;16(7):655-60. https://doi.org/10.1093/treephys/16. 7.655

28. Allen G. The shapes of leaves1. Nature. 1883;27(698):464-6. https://doi.org/1 $0.1038 / 027464 \mathrm{aO}$

29. Niklas KJ. Research review: a mechanical perspective on foliage leaf form and function. New Phytol. 1999;143(1):19-31. https://doi.org/10.1046/j.14698137.1999.00441x

30. McCulloh KA, Sperry JS, Adler FR. Water transport in plants obeys Murray's law. Nature. 2003:421(6926):939-42. https://doi.org/10.1038/nature01444.

31. Mcculloh KA, Sperry JS, Adler FR. Murray's law and the hydraulic vs mechanical functioning of wood. Funct Ecol. 2004;18(6):931-8. https://doi. org/10.1111/j.0269-8463.2004.00913.x.

32. Bentley LP, Stegen JC, Savage VM, Smith DD, von Allmen El, Sperry JS, et al. An empirical assessment of tree branching networks and implications for plant allometric scaling models. Ecol Lett. 2013;16(8):1069-78. https://doi. org/10.1111/ele.12127.

33. Olson ME, Anfodillo T, Rosell JA, Petit G, Crivellaro A, Isnard S, et al. Universal hydraulics of the flowering plants: vessel diameter scales with stem length across angiosperm lineages, habits and climates. Ecol Lett. 2014:17(8):988-97. https://doi.org/10.1111/ele.12302.

34. Fichot R, Chamaillard S, Depardieu C, Le Thiec D, Cochard H, Barigah TS, et al. Hydraulic efficiency and coordination with xylem resistance to cavitation, leaf function, and growth performance among eight unrelated Populus deltoidesXPopulus nigra hybrids. J Exp Bot. 2011;62(6):2093-106. https://doi.org/10.1093/jxb/erq415.

35. Zhao M, Xiang W, Deng X, Tian D, Huang Z, Zhou X, et al. Application of TRIPLEX model for predicting Cunninghamia lanceolata and Pinus massoniana forest stand production in Hunan Province, southern China. Ecol Model. 2013;250:58-71. https://doi.org/10.1016/j.ecolmodel.2012.10.011.

36. Zhao M, Xiang W, Peng C, Tian D. Simulating age-related changes in carbon storage and allocation in a Chinese fir plantation growing in southern China using the 3-PG model. For Ecol Manag. 2009;257(6):1520-31. https://doi. org/10.1016/j.foreco.2008.12.025

37. Frey J. Ekomorfologitsheskii analiz hvoi yeli i pologa yelnika (Ecomorphological analysis of the spruce needle and spruce stand). Cand. Biol: Dissertation, Tartuskii Gosudarstvennyi Universitet. In Russian; 1981. p. 155

38. Niinemets $\ddot{U}$, Kull O. Effects of light availability and tree size on the architecture of assimilative surface in the canopy of Picea abies: variation in needle morphology. Tree Physiol. 1995;15(5):307-15. https://doi.org/10.1093/ treephys/15.5.307.

39. Reich A, Sharifi M, Connors C, Bentley B, Rundel P. Comparative phenology and water relations of yellow bush lupine (Lupinus arboreus Sims., Fabaceae) in the coastal dunes of north-Central California: evidence of variable herbivore tolerance. J Mediterr Ecol. 2002;3:3-14.

40. Reich A, Holbrook NM, Ewel JJ. Developmental and physiological correlates of leaf size in Hyeronima alchorneoides (Euphorbiaceae). Am J Bot. 2004; 91(4):582-9. https://doi.org/10.3732/ajb.91.4.582.

41. Apple M, Tiekotter K, Snow M, Young J, Soeldner A, Phillips D, et al. Needle anatomy changes with increasing tree age in Douglas-fir. Tree Physiol. 2002 22(2-3):129-36. https://doi.org/10.1093/treephys/22.2-3.129. 
42. Traiser C, Klotz S, Uhl D, Mosbrugger V. Environmental signals from leaves-a physiognomic analysis of European vegetation. New Phytol. 2005;166(2): 465-84. https://doi.org/10.1111/j.1469-8137.2005.01316.x.

43. Li Y, Zou D, Shrestha N, Xu X, Wang Q, Jia W, et al. Spatiotemporal variation in leaf size and shape in response to climate. J Plant Ecol. 2020;13(1):87-96. https://doi.org/10.1093/jpe/rtz053.

44. Becker P, Gribben RJ, Lim CM. Tapered conduits can buffer hydraulic conductance from path-length effects. Tree Physiol. 2000;20(14):965-7. https://doi.org/10.1093/treephys/20.14.965.

45. Sperry JS, Meinzer FC, McCULLOH KA. Safety and efficiency conflicts in hydraulic architecture: scaling from tissues to trees. Plant Cell Environ. 2008; 31(5):632-45. https://doi.org/10.1111/j.1365-3040.2007.01765.x.

46. Moulia B, Fournier M. Mechanics of the maize leaf: a composite beam model of the midrib. J Mater Sci. 1997;32(10):2771-80. https://doi.org/10.1 023/A:1018604012754

47. Anfodillo T, Carraro V, Carrer M, Fior C, Rossi S. Convergent tapering of xylem conduits in different woody species. New Phytol. 2006;169(2):279-90. https://doi.org/10.1111/j.1469-8137.2005.01587.x.

48. Yamada T, Takemoto M, Okuda T. Leaf morphology correlated with height location in the emergent tree, Dipterocarpus sublamellatus in a Malaysian rain forest. Hikobia. 2014;16:433-40.

49. Niklas KJ. Plant biomechanics: an engineering approach to plant form and function: University of Chicago press; 1992.

50. Hacke UG, Lachenbruch B, Pittermann J, Mayr S, Domec J-C, Schulte PJ. The hydraulic architecture of conifers; 2015. p. 39-75.

51. Bouche PS, Larter M, Domec J-C, Burlett R, Gasson P, Jansen S, et al. A broad survey of hydraulic and mechanical safety in the xylem of conifers. J Exp Bot. 2014;65(15):4419-31. https://doi.org/10.1093/jxb/eru218.

52. Sebastian-Azcona J, Hacke UG, Hamann A. Adaptations of white spruce to climate: strong intraspecific differences in cold hardiness linked to survival. Ecol Evol. 2018;8(3):1758-68. https://doi.org/10.1002/ece3.3796.

53. Nardini A, Salleo S. Effects of the experimental blockage of the major veins on hydraulics and gas exchange of Prunus laurocerasus L. leaves. J Exp Bot. 2003;54(385):1213-9. https://doi.org/10.1093/jxb/erg130.

54. Brodribb TJ, Holbrook NM. Water stress deforms tracheids peripheral to the leaf vein of a tropical conifer. Plant Physiol. 2005;137(3):1139-46. https://doi. org/10.1104/pp.104.058156.

55. Kitajima K. Relative importance of photosynthetic traits and allocation patterns as correlates of seedling shade tolerance of 13 tropical trees. Oecologia. 1994;98(3):419-28. https://doi.org/10.1007/BF00324232.

56. Sack L, Tyree MT. Leaf hydraulics and its implications in plant structure and function. In: Vascular transport in plants: Academic; 2005. p. 93-114.

57. Poorter $\mathrm{H}$, Nagel $\mathrm{O}$. The role of biomass allocation in the growth response of plants to different levels of light, $\mathrm{CO}_{2}$, nutrients and water: a quantitative review. Funct Plant Biol. 2000;27(12):1191.

58. Falster DS, Duursma RA, FitzJohn RG. How functional traits influence plant growth and shade tolerance across the life cycle. Proc Natl Acad Sci U S A 2018;115(29):E6789-E98. https://doi.org/10.1073/pnas.1714044115.

59. Kleyer M, Trinogga J, Cebrián-Piqueras MA, Trenkamp A, Fløjgaard C, Ejrnæs $R$, et al. Trait correlation network analysis identifies biomass allocation traits and stem specific length as hub traits in herbaceous perennial plants. J Ecol. 2019;107(2):829-42. https://doi.org/10.1111/1365-2745.13066.

60. Westoby $M$, Wright IJ. The leaf size-twig size spectrum and its relationship to other important spectra of variation among species. Oecologia. 2003; 135(4):621-8. https://doi.org/10.1007/s00442-003-1231-6.

61. Niinemets $U$, Portsmuth A, Tena D, Tobias M, Matesanz S, Valladares F. Do we underestimate the importance of leaf size in plant economics? Disproportional scaling of support costs within the spectrum of leaf physiognomy. Ann Bot. 2007;100(2):283-303. https://doi.org/10.1093/aob/mcm107.

62. McCulloh KA, Sperry JS. Patterns in hydraulic architecture and their implications for transport efficiency. Tree Physiol. 2005;25(3):257-67. https:// doi.org/10.1093/treephys/25.3.257.

63. Petit G, Anfodillo T, Mencuccini M. Tapering of xylem conduits and hydraulic limitations in sycamore (Acer pseudoplatanus) trees. New Phytol. 2008;177(3):653-64. https://doi.org/10.1111/j.1469-8137.2007.02291.x.

64. Petit G, Pfautsch S, Anfodillo T, Adams MA. The challenge of tree height in Eucalyptus regnans: when xylem tapering overcomes hydraulic resistance. New Phytol. 2010;187(4):1146-53. https://doi.org/10.1111/j.1469-8137.2010.03304.x.

65. Tyree MT, Ewers FW. The hydraulic architecture of trees and other woody plants. New Phytol. 1991;119(3):345-60. https://doi.org/10.1111/j.1469-8137.1 991.tb00035.x
66. Scoffoni C, Albuquerque C, Brodersen CR, Townes SV, John GP, Cochard H, et al. Leaf vein xylem conduit diameter influences susceptibility to embolism and hydraulic decline. New Phytol. 2017;213(3):1076-92. https:// doi.org/10.1111/nph.14256

67. Pittermann J, Sperry JS, Hacke UG, Wheeler JK, Sikkema EH. Inter-tracheid pitting and the hydraulic efficiency of conifer wood: the role of tracheid allometry and cavitation protection. Am J Bot. 2006;93(9):1265-73. https:// doi.org/10.3732/ajb.93.9.1265

68. Pittermann J, Stuart SA, Dawson TE, Moreau A. Cenozoic climate change shaped the evolutionary ecophysiology of the Cupressaceae conifers. Proc Natl Acad Sci U S A. 2012;109(24):9647-52. https://doi.org/10.1073/pna s.1114378109.

69. Givnish T. Optimal stomatal conductance, allocation of energy between leaves and roots, and the marginal cost of transpiration. In: On the economy of plant form and function: proceedings of the sixth Maria moors Cabot symposium, evolutionary constraints on primary productivity, adaptive patterns of energy capture in plants, Harvard Forest, august 1983. Cambridge [Cambridgeshire]: Cambridge University Press, c1986; 1986.

70. Goldberg D, Wildová R, Herben T. Consistency vs. contingency of traitperformance linkages across taxa. Evol Ecol. 2008;22(3):477-81. https://doi. org/10.1007/s10682-007-9223-3.

71. Jones HG. Plants and microclimate: a quantitative approach to environmental plant physiology: Cambridge University Press; 2013. https:// doi.org/10.1017/CBO9780511845727.

72. Bond BJ. Age-related changes in photosynthesis of woody plants. Trends Plant Sci. 2000;5(8):349-53. https://doi.org/10.1016/S1360-1385(00)01691-5.

73. Dayrell RL, Arruda AJ, Pierce S, Negreiros D, Meyer PB, Lambers H, et al. Ontogenetic shifts in plant ecological strategies. Funct Ecol. 2018;32(12): 2730-41. https://doi.org/10.1111/1365-2435.13221.

74. Schneider FD, Morsdorf F, Schmid B, Petchey OL, Hueni A, Schimel DS, et al. Mapping functional diversity from remotely sensed morphological and physiological forest traits. Nat Commun. 2017;8(1):1-12.

75. Brodribb TJ, Feild TS, Sack L. Viewing leaf structure and evolution from a hydraulic perspective. Funct Plant Biol. 2010;37(6):488. https://doi.org/10.1 071/FP10010.

76. R Core Team. R: a language and environment for statistical computing. Vienna: R foundation for statistical computing, Austria; 2019.

\section{Publisher's Note}

Springer Nature remains neutral with regard to jurisdictional claims in published maps and institutional affiliations.

Ready to submit your research? Choose BMC and benefit from:

- fast, convenient online submission

- thorough peer review by experienced researchers in your field

- rapid publication on acceptance

- support for research data, including large and complex data types

- gold Open Access which fosters wider collaboration and increased citations

- maximum visibility for your research: over $100 \mathrm{M}$ website views per year

At $\mathrm{BMC}$, research is always in progress.

Learn more biomedcentral.com/submission 